\title{
TUMOR NECROSIS FACTOR-ALPHA AS BIOMARKERS OF EXPOSURE TO INDOOR POLLUTANTS AMONG PRIMARY SCHOOL CHILDREN IN KLANG VALLEY
}

\author{
${ }^{1}$ Juliana Jalaludin, ${ }^{1}$ Sharifah Nazariah Syed Noh, \\ ${ }^{1}$ Nur Faseeha Suhaimi and ${ }^{2}$ Abdah Md Akim \\ ${ }^{1}$ Department of Environmental and Occupational Health, \\ Faculty of Medicine and Health Sciences, University Putra Malaysia, Malaysia \\ ${ }^{2}$ Department of Biomedical Sciences, Faculty of Medicine and Health Sciences, UPM, Malaysia
}

Received 2012-12-20; Revised 2014-01-03; Accepted 2014-08-11

\begin{abstract}
Poor indoor air quality can be particularly harmful to children and interfere with the growth of their lung function as they spend much of their time indoors. In order to understand the mechanism of exposure in the airways, biomarkers were used as a surrogate for biological responses towards indoor air pollutants. This study aims to investigate the association between indoor air pollutants $\left(\mathrm{PM}_{2.5}, \mathrm{PM}_{10}\right.$ and $\left.\mathrm{NO}_{2}\right)$ among school children in different area of urban and rural site in Klang Valley. A cross sectional comparative study was conducted among 430 healthy schoolchildren from a national primary school. Methods involved questionnaires based on American Thoracic Society and sputum samples for biomarkers assay. Indoor exposure to $\mathrm{PM}_{2.5}$ and $\mathrm{PM}_{10}$ (Dust Trak Aerosol Monitor) and $\mathrm{NO}_{2}$ (LaMotte Air Sampler) were measured in the classroom. Mean concentration of $\mathrm{PM}_{2.5}\left(50.72 \mu \mathrm{g} / \mathrm{m}^{3}\right)$ in urban schools were significantly higher compared to rural $\left(28.36 \mu \mathrm{g} / \mathrm{m}^{3}\right)$ school. Similar trend found in indoor level of $\mathrm{PM}_{10}$ in urban and rural schools with $87.04 \mu \mathrm{g} / \mathrm{m}^{3}$ and $56.76 \mu \mathrm{g} / \mathrm{m}^{3}$ respectively. The mean exposure level of $\mathrm{NO}_{2}$ of urban schools $(0.12 \mathrm{ppm})$ is nearly 4 times higher than the level in rural areas $(0.032 \mathrm{ppm})$. A significant association was found between indoor air concentrations $\left(\mathrm{PM}_{2.5}\right.$ and $\left.\mathrm{PM}_{10}\right)$ with TNF-alpha level. Children from rural areas are exposed to less air pollutants compared to those from urban area and this study also suggests that higher exposure to $\mathrm{PM}_{2.5}, \mathrm{PM}_{10}$ and $\mathrm{NO}_{2}$ are associated with increasing of TNF-alpha level.
\end{abstract}

Keywords: School Children, Rural, Urban, $\mathrm{PM}_{2.5}, \mathrm{PM}_{10}, \mathrm{NO}_{2}$, Tumor Necrosis Factor

\section{INTRODUCTION}

Children are more vulnerable to serious health risks from environmental hazards compared to adults. As children are always exposed indoors (80\%), it is important to examine pollution where they spend most time at, as well as in the places where the ambient levels are high (Heinrich, 2011). Thus, indoor air quality in schools is one of special concern for children exposure due to pollutant levels in indoor school are often 2 to 5 times higher compared to outdoors (Mercola, 2011; USEPA, 2011). Even at low concentrations, the presence of indoor pollutants may have important biological impact if it is exposed in long periods. Thus, the morbidity risks may be greater due to their exposure to indoor air pollution rather than outdoors especially among children (Ismail et al., 2010). This is supported by a study from the World Health Organization (WHO) indicated approximately, 3.5 million people die early annually from indoor air pollution and 3.3 million from outdoor air pollution (Reuters, 2013). The effects of air pollution on respiratory symptoms (Gül et al., 2011; Liu et al., 2013; Tabaku et al., 2011), asthma attacks (Zakaria et al., 2012) and lung function (Linares et al., 2010) have been shown.

\section{Corresponding Author: Juliana Jalaludin, Department of Environmental and Occupational Health, Faculty of Medicine and Health Sciences, University Putra Malaysia (43400), Malaysia Tel: +603-89472401}


Since children spend more time in school (Naziah et al., 2011), they are susceptible to poor air quality which substantially impact on children's health Pegas et al., 2010). It is a concern that children have a greater ventilation rate per body weight or pulmonary surface area as compared to adults (Ashmore and Dimitroulopoulou, 2009; Gilliland, 2009; Mohd Sofian and Ismail, 2012). Moreover, children's bodies are still developing and the effect of environmental risk can interfere with the growth of their lung function as well as their immune systems and permitting infections to their body (Edwards and Langpap, 2012). The last two periods showed the potential significance of poor air quality for the children's health, which exposed them to air pollutants in indoor environments (Chatzidiakou et al., 2012) especially in urban area (Padhi et al., 2010).

On This current time, Malaysia is experiencing rapid urbanization (Masron et al., 2012). The urban population in Malaysia has increased from $62 \%$ in 2000 to $71 \%$ in 2010 (DSM, 2011). The growth of urban population in Malaysia was more rapid than the population growth in rural areas (Ngah, 2010). One of the most developed areas in Malaysia is Klang Valley, which involve rapid urbanization and industrialization activities (Azmi et al., 2010; Ling et al., 2010). Due to this concern, Klang Valley is continuously exposed to air pollution, which is approaching critical levels in a number of urban areas including Kuala Lumpur and Petaling Jaya (Musa et al., 2013). Thus, indoor environment in Malaysia is one of the particular interests to study where building-related illnesses still have not gained the same importance as those related to outdoor air quality (Shaharom, 2013). Furthermore, Malaysia is a tropical country, which has a lower ventilation rates, therefore enhancing the usage of open ventilation system in such buildings. Likewise, national primary schools in Malaysia use general (open) air ventilation, which makes it easier for the particles or gases to go into the classrooms.

Biomarkers are used as surrogates for biological responses towards indoor air pollutants in order to understand the relationship of indoor air exposure among school children and inflammation of their lungs. The biomarkers involved are pro-inflammatory cytokines, which are Tumor Necrosis Factor-alpha (TNF- $\alpha)$. These pro-inflammatory cytokines have been investigated mostly for their anti-inflammatory actions. TNF- $\alpha$ has also been suggested to have a key-role in particleinduced inflammation study ( Baune et al., 2012) and it has been concluded that TNF- $\alpha$ can induce an increase in airway responsiveness in healthy subjects, thus making it a cytokine candidate for the induction of airway inflammation and hyper responsiveness (Elahi et al., 2009,
Montgomery and Bowers, 2012). This research is intended to observe the effects of exposure to selected indoor air pollutants through the reaction of biological samples, which indicate the susceptibility of lung inflammation. As to our knowledge, this is the first study of indoor air pollutants among school children, which is documenting on indoor air exposure using sputum induction as a biomarker in Malaysia.

\section{MATERIALS AND METHODS}

This study is a cross sectional comparative study conducted in national primary schools located in Klang Valley, which consists of the Federation of Kuala Lumpur and Selangor. Klang Valley is one of the developing areas with major sources of pollutants are released by transport vehicles and industrial emissions, which may affect the population around it. Based on cluster random sampling method, the area of sampling was divided into two regions. In the same region, this study was performed in two different areas: Urban area was conducted in Petaling Jaya; rural area was represented by Beranang (Selangor).

\subsection{Selection of Schools}

A list of grades of classified National Primary School situated in Klang Valley was acquired from the Ministry of Health with criteria of more than 1000 children per school. The list was distinguished from urban to rural area which is not in close proximity to industrialization activities. Urban here is referred as the special development area that can be identified, which at least had a population of 10,000 with at least $60 \%$ of the population (aged 15 years and above) are involved in non-agricultural activities (30 Department of Statistic, 2010). Furthermore, the selection of schools was based on the different sites of human activities of urban and rural which are located within $5 \mathrm{~km}$ radius to ASMA air pollution monitoring station. The schools were randomly selected involving two primary schools in urban specifically Sri Petaling and Bandar Tun Razak, while Beranang represents rural area (Fig. 1). Primary education system in Malaysia begins at the age of 7 to age 12, which respectively starts from Standard 1 to 6 . Permission from the Malaysia Ministry of Education was obtained prior to carry out the study in primary schools covering Kuala Lumpur and Selangor districts. Both urban and rural schools selected were using general ventilation, which ease these air pollutants to penetrate in and out of the classrooms. 


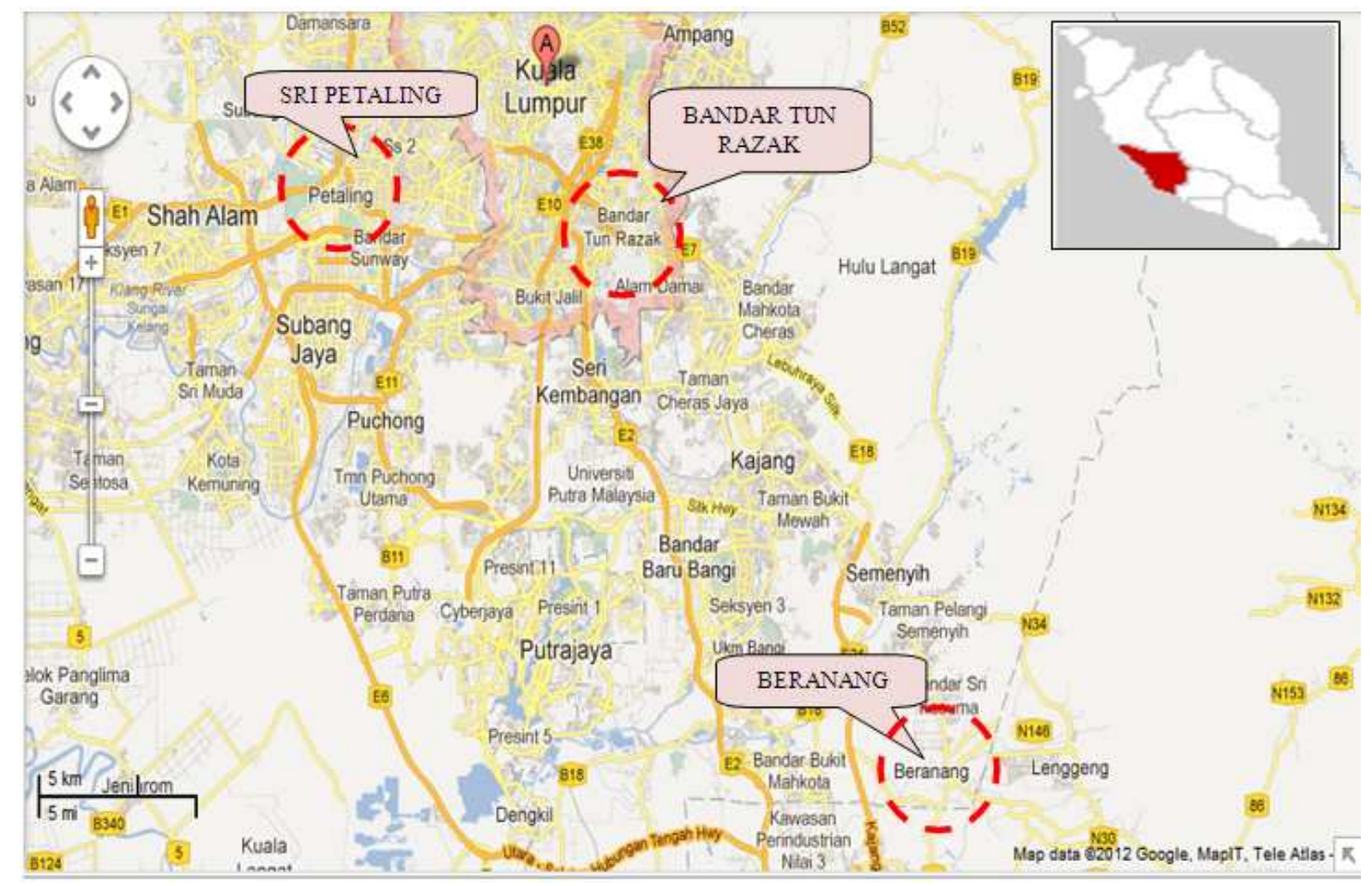

Fig. 1. Map of sampling location

\subsection{Selection of School Children}

For each selected school, all children in Standard 2 (8 years old) and Standard 5 (11 years old) who had never been diagnosed with any respiratory diseases were invited at the beginning of the study. The selection was based from the name list obtained from medical school records. Only Malay students were being selected as most of the school children in national primary schools are Malays. Each child selected then was sampled based on the distance of their houses to be less than $5 \mathrm{~km}$ away from their schools to minimize the potential of confounder in the study.

\subsection{Ethical Approval}

Approval from the Committee of Ethics of Faculty of Medicine and Health Sciences, University Putra Malaysia was obtained. Permission to conduct this study was acquired from the Malaysia Ministry of Education, which cover schools in Kuala Lumpur and Selangor districts. Moreover, approvals from the respective schools were also acquired to ensure the data collection was done during appropriate time.
Written consents from parents or guardians were obtained prior to data collection. The privacy of the information gathered is confidential and was protected during all phases of study. Sputum sample was collected from the children after getting the parents' or guardians' permission.

\subsection{Questionnaires}

Questionnaires that were completed by parents or guardians were returned by the children within 2 days. This questionnaire was based on standardized questionnaire that was adapted from American Thoracic Society's Division of Lung Diseases (ATS-DLD-78-C) and were then modified and translated from English to Malay language. The questions mainly addressed the variables which have been reviewed in the literature, such as; respiratory symptoms, home environmental exposures, lung disease history and socio-demographic information. Any returned questionnaire with incomplete answers were contacted by the researcher through the phone. Prior to the study, a pre-test questionnaire was carried out among parents as to 
verify the reliability of the questionnaires to ensure the contents were easily understood.

\subsection{Sampling}

The study performed indoor measurement in classroom environments to understand the children's exposure. The measurement of indoor air pollutants was conducted in the classrooms during the school period of $5 \mathrm{~h}$ depending on the school session (morning or evening). Generally, Standard 5 is in the morning session, while Standard 2 is in the evening session. The measurement was conducted with the present of school children and teachers in the classrooms. Sampling technique used is a directreading instrument method of air sampling tool (Dust Trak Aerosol Monitor) (TSI) to measure aerosol with an upper particle size limit of $10 \mu \mathrm{m}$. Mean while, measurement of $\mathrm{NO}_{2}$ levels was carried out using LaMotte Air Pollution Test Equipment, which uses absorption method. The level of $\mathrm{NO}_{2}$ was determined using the $\mathrm{NO}_{2}$ spectrophotometer by reading the absorbance wavelength. Prior to monitoring, two Dust Trak Aerosol Monitors were fitted with $\mathrm{PM}_{2.5}$ and $\mathrm{PM}_{10}$ inlets, while LaMotte was set with the chemical reagents. During the monitoring in the classrooms, both instruments were placed on desks at $1.5 \mathrm{~m}$ above floor level (Lee and Chang, 2000) at the back of the classrooms and located at least $0.5 \mathrm{~m}$ away from the children to make sure it does not interrupt the class activities.

\subsection{Sputum Samples}

Sputum was collected upon granted permission by parent or guardian and return of completed questionnaire. Sputum samples then were taken during school hours by inducing children using dense aerosol of hypertonic or normal saline. The technique has been successfully applied to induce sputum from normal or healthy children which was based on the study conducted by (Gibson, 1998). Children were requested to inhale hypertonic saline $(\mathrm{NaCl} 4.5 \%)$ for 5 to $20 \mathrm{~min}$ through ultrasonic nebulizer. Samples from sputum induction were collected in a specimen bottle before being transported and stored at $-80^{\circ} \mathrm{C}$ in the laboratory.

\subsection{Human Tumor Necrosis Factor-Alpha (TNF- $\alpha)$}

The concentration of TNF- $\alpha$ were analyzed using human Enzyme-Linked Immuno Sorbent Assay (ELISA or EIA) which was based on manufacturer's instruction. The TNF- $\alpha$ concentration was quantified after incubation with detection of antibody. Collected sputum was ultracentrifuged for $8,000 \times \mathrm{g}$ for $20 \mathrm{~min}$ $4{ }^{\circ} \mathrm{C}$ (Delacourt et al., 2002) and kept under- $80^{\circ} \mathrm{C}$ until the sample were analyzed.

The concentrations of TNF- $\alpha$ were calculated by extrapolating samples to the standard curve graph. Sputum analysis of human TNF- $\alpha$ was carried out in Chemical Pathological Laboratory, Department of Pathology and University Putra Malaysia.

\subsection{Statistical Analysis}

Data were entered and analyzed concerning the concentration of Indoor Air Quality (IAQ) and the level of Tumor-Necrosis Factor alpha (TNF- $\alpha$ ) according to the area of residence. The comparisons between the two areas were tested using independent t-test. The Pearson correlation was conducted to determine the relationship between different indoor air pollutants at each area with the level of TNF- $\alpha$. To explore the factors influencing the level of $\mathrm{TNF}-\alpha$, multiple logistic regression models were used in which the potential confounding factors were controlled. All statistical analyses were performed using the Statistical Packages for Social Sciences (SPSS). All $\mathrm{p}$ values reported are 2-tailed with statistical significance set at $<0.05$.

\section{RESULTS}

\subsection{Response Rate}

From the lists of sampling frame obtained from school medical records, there were 250 initial questionnaires for children in Standard 2 and Standard 5 who had never been diagnosed with any respiratory diseases from the selected schools of urban and rural. A number of $232(92.8 \%)$ school children from the initial samples in urban area were willing to participate in this study. Meanwhile, there were only $198(79.2 \%)$ responses from the parents or guardians in rural areas who agreed with the permission to participate in the sputum collection.

\subsection{Socio-Demographic Information}

The distributions of background information are shown in Table $\mathbf{1}$ and 2 . Table $\mathbf{1}$ provides the comparison of demographic background of the samples between two areas. The table showed highly significant differences in parental education and types of housing between school children who live in urban area and those who live in rural area. Meanwhile, there was no significant difference obtained for crowding ration in both urban and rural area (Table 2). 
Table 1. Distribution of backgrounds among selected schoolchildren in Klang Valley

\begin{tabular}{|c|c|c|c|c|}
\hline Variables & Urban $(\mathrm{n}=232)$ number $(\%)$ & Rural $(\mathrm{n}=198)$ number $(\%)$ & $\chi^{2}$ value & $\mathrm{P}$ value \\
\hline \multicolumn{5}{|c|}{ Education level (Father) } \\
\hline Primary education & $1(4)$ & $25(12.6)$ & \multirow{4}{*}{43.07} & \multirow{3}{*}{$<0.001 * *$} \\
\hline Secondary education & $108(46.6)$ & $141(71.2)$ & & \\
\hline Higher education & $123(53)$ & $32(16.2)$ & & \\
\hline \multicolumn{4}{|c|}{ Education level (Mother) } & \\
\hline Primary education & $3(1.3)$ & $40(20.2)$ & \multirow{3}{*}{10.39} & \multirow{3}{*}{$<0.001 * *$} \\
\hline Secondary education & $141(60.8)$ & $130(65.7)$ & & \\
\hline Higher education & $88(37.9)$ & $28(14.1)$ & & \\
\hline \multicolumn{5}{|l|}{ Types of housing } \\
\hline Bungalow & $14(6)$ & $3(1.5)$ & \multirow{5}{*}{42.47} & \multirow{5}{*}{$0.001 * *$} \\
\hline Apartment & $92(39.7)$ & $9(4.5)$ & & \\
\hline Single storey terrace & $52(21.6)$ & $96(48.5)$ & & \\
\hline Double storey terrace & $76(32.8)$ & $25(12.6)$ & & \\
\hline Village & $0(0)$ & $57(28.8)$ & & \\
\hline
\end{tabular}

**Significant at $\mathrm{p}<0.001$

Table 2. Comparison of socioeconomic backgrounds

\begin{tabular}{|c|c|c|c|c|}
\hline Variables & $\begin{array}{l}\text { Urban }(\mathrm{n}=232) \text { number }(\%) \\
\text { median (IQR) }\end{array}$ & $\begin{array}{l}\text { Rural }(\mathrm{n}=198) \text { number }(\%) \\
\text { median }(\mathrm{IQR})\end{array}$ & $\mathrm{z}$ value & $\mathrm{P}$ value \\
\hline Total income (RM) & $4700(3500)$ & $2275(1500)$ & -11.69 & $0.001 * *$ \\
\hline Total dweller & $5(1)$ & $6(1)$ & -2.15 & $0.31 *$ \\
\hline Total room & $3(1)$ & $3(1)$ & -4.19 & $0.001 * *$ \\
\hline Crowding ration & $1.7(0.7)$ & $1.8(0.5)$ & -0.039 & 0.969 \\
\hline
\end{tabular}

** Significant at $\mathrm{p}<0.001$

\subsection{Indoor Air Levels of $\mathrm{PM}_{2.5}, \mathrm{PM}_{10}$ and $\mathrm{NO}_{2}$ in Schools of Urban and Rural}

Table 3 shows a comparison of concentration of indoor air pollutant levels of $\mathrm{PM}_{2.5}, \mathrm{PM}_{10}$ and $\mathrm{NO}_{2}$ between schools in urban and rural areas. Concentration of $\mathrm{PM}_{2.5}$ was measured by air sampling monitoring (Dust Trak Aerosol Monitor) for indoor $\mathrm{PM}_{2.5}$ concentration among the study areas. The mean concentration of $\mathrm{PM}_{2.5}$ inside the classrooms of urban schools ( 28.2 to $65.5 \mu \mathrm{g} / \mathrm{m}^{3}$ ) was 1.8 higher than the mean concentration of indoor $\mathrm{PM}_{2.5}$ inside the classrooms of rural schools (22.75 to $\left.37.77 \mu \mathrm{g} / \mathrm{m}^{3}\right)$. Dust Trak Aerosol Monitor was also used as a tool to monitor the indoor levels of $\mathrm{PM}_{10}$. Comparison of indoor aerosol levels for $\mathrm{PM}_{10}$ inside classrooms showed similar tabulation between the two areas (Table 3). Mean concentration level of $\mathrm{PM}_{10}$ in schools in urban area $\left(52.9\right.$ to $\left.121.3 \mu \mathrm{g} / \mathrm{m}^{3}\right)$ was also higher compared to the schools in rural area (43.61 to $69.59 \mu \mathrm{g} / \mathrm{m}^{3}$ ). Both indoor particulate matters inside classrooms showed a significant difference $(\mathrm{p}<0.001)$ between the study schools.

Measurement of concentration of indoor $\mathrm{NO}_{2}$ was measured by the LaMotte Air Sampler Test, which measures the rate of flow of the air through the absorbing principles of calorimetric. The statistical analysis records that the mean value of $\mathrm{NO}_{2}$ levels in urban classrooms were nearly 4 times higher compared to rural schools with ranged between 0.533 to 0.1844 ppm (urban). The distribution of $\mathrm{NO}_{2}$ concentrations between study group areas indicate high significant difference $(\mathrm{P}=0.001)$ and $\mathrm{t}$ value of 32.29.

\subsection{Prevalence of Respiratory Symptoms}

Respiratory symptoms were identified using the questionnaire which was answered by parents or guardians. The parameters for respiratory symptoms studied were cough, phlegm, chest tightness and wheezing. As presented in Table 4, the differences in prevalence of respiratory symptoms among school children showed a significant difference for all parameters $(\mathrm{p}<0.05)$ except chest tightness. No reported data was received for chest tightness by the parents or guardians in urban areas.

\subsection{Comparison of TNF- $\alpha$ Level}

Biomarkers were used to understand the physiology of inflammation of human respiratory system affected by inhalation of indoor air pollutants by school children. 
Tumor Necrosis Factor-alpha (TNF- $\alpha$ ) was used in place of the biomarkers for respiratory systems as it plays a part in respiratory inflammation. The sputum samples taken from the children were being analyzed in order to get TNF- $\alpha$ concentration levels.

According to the statistical analysis, the TNF- $\alpha$ level among children in urban and rural areas differ significantly with $7.35 \pm 2.92$ and $5.61 \pm 2.53 \mathrm{pg} \mathrm{mL}$, respectively (Table 5). In summary, the statistical analysis described that the mean value of TNF- $\alpha$ concentration levels for children in urban was significantly higher than children in rural. Comparison between these two study areas were observed with significant difference and shows z-value of $-5.951(\mathrm{p}<0.001)$.

\subsection{Association between Indoor Air Concentration Parameters and TNF- $\alpha$ Level}

The data was recorded and analyzed using Spearman Correlation tests to see the association between indoor $\mathrm{PM}_{2.5}, \mathrm{PM}_{10}$ and $\mathrm{NO}_{2}$ concentration with the production of TNF- $\alpha$ level among school children (Table 6). There were significant correlations between indoor air concentration of $\mathrm{PM}_{10}(\mathrm{r}=0.475$, $\mathrm{p}<0.001), \mathrm{PM}_{2.5}(\mathrm{r}=0.493, \mathrm{p}<0.001)$ and $\mathrm{NO}_{2}(\mathrm{r}=$ $0.329, \mathrm{p}=0.001$ ) with TNF- $\alpha$ level in the urban school area. Moreover, a significant correlation was also found between all indoor air concentration and the level of TNF- $\alpha$ for the school children who study in rural areas, of $\mathrm{PM}_{10}(\mathrm{r}=0.206, \mathrm{p}<0.004), \mathrm{PM}_{2.5}(\mathrm{r}=$ $0.356, \mathrm{p}<0.001)$ and $\mathrm{NO}_{2}(\mathrm{r}=0.321, \mathrm{P}=0.001)$.

\subsection{Factors Influencing the Concentration of TNF-a Among School Children}

Linear regressions were performed to determine the main factor contributing towards TNF- $\alpha$ of school children. The analysis included exposure level of $\mathrm{PM}_{10}, \mathrm{PM}_{2.5}$ and $\mathrm{NO}_{2}$ of school children. As presented in Table 7, results from analysis revealed that the exposure level of $\mathrm{PM}_{10}$ and $\mathrm{PM}_{2.5}$ recorded had significantly influenced the concentration of TNF- $\alpha$ among the school children.

Table 3. Comparison of Indoor Air Pollutants inside Classroom between Urban and Rural

\begin{tabular}{lclll}
\hline & Urban $(\mathrm{n}=232)$ number $(\%)$ & Rural $(\mathrm{n}=198)$ number $(\%)$ & & \\
Variables & Mean $(\mathrm{SD})$ & Mean $(\mathrm{SD})$ & t value & P value \\
\hline $\mathrm{PM}_{2.5}\left(\mu \mathrm{g} / \mathrm{m}^{3}\right)$ & $50.72(10.65)$ & $28.36(4.41)$ & 27.61 & $<0.001$ \\
$\mathrm{PM}_{10}\left(\mu \mathrm{g} / \mathrm{m}^{3}\right)$ & $87.04(16.35)$ & $56.76(6.7)$ & 24.37 & $<0.001$ \\
$\mathrm{NO}_{2}(\mathrm{ppm})$ & $0.121(0.038)$ & $0.032(0.006)$ & 32.29 & $<0.001$ \\
\hline
\end{tabular}

**Significant at $\mathrm{p}<0.001$

Table 4. Comparison of respiratory symptoms among school children

\begin{tabular}{|c|c|c|c|c|c|c|c|}
\hline Variable & & $\begin{array}{l}\text { Urban }(\mathrm{n}=232) \\
\text { number }(\%)\end{array}$ & $\begin{array}{l}\text { Rural }(\mathrm{n}=198) \\
\text { number }(\%)\end{array}$ & $X^{2}$ & $\mathrm{P}$ value & $\begin{array}{l}\text { Odd } \\
\text { ratio }\end{array}$ & $95 \% \mathrm{CI}$ \\
\hline \multirow[t]{2}{*}{ Cough } & Yes & $73(31.5)$ & $44(22.2)$ & 4.608 & 0.039 & 1.607 & $1.040-2.482$ \\
\hline & No & $159(68.5)$ & $154(77.8)$ & & & & \\
\hline \multirow[t]{2}{*}{ Phlegm } & Yes & $47(20.3)$ & $22(11.6)$ & 6.635 & 0.012 & 2.032 & $1.176-3.511$ \\
\hline & No & $185(79.7)$ & $176(88.9)$ & & & & \\
\hline \multirow[t]{2}{*}{ Wheezing } & Yes & $31(13.4)$ & $2(1)$ & 18.379 & 0.001 & 7.48 & $2.592-21.586$ \\
\hline & No & $201(86.6)$ & $196(99)$ & & & & \\
\hline Chest & Yes & $(0)$ & $2(1.0)$ & 2.354 & 0.211 & - & - \\
\hline Tightness & No & $232(100)$ & $196(99.0)$ & & & & \\
\hline
\end{tabular}

**Significant at $\mathrm{p}<0.05 ; * *$ Significant at $\mathrm{p}<0.001$

Table 5. Comparison of TNF- $\alpha$ between schoolchildren in urban and rural area

\begin{tabular}{lllll}
\hline Variable & $\begin{array}{l}\text { Urban }(\mathrm{n}=198) \\
\text { median }(\mathrm{IQR})\end{array}$ & $\begin{array}{l}\text { Rural }(\mathrm{n}=198) \\
\text { median }(\mathrm{IQR})\end{array}$ & Z value & P value \\
\hline $\mathrm{TNF}-\alpha(\mathrm{pg} / \mathrm{mL})$ & $7.04(3.45)$ & $5.42(3.84)$ & -5.951 & $<0.001^{* *}$ \\
\hline$* *$ Significant at $\mathrm{p}<0.001$ & & & & \\
$\mathrm{PP}$ PS Science Publications & & 1621 & & AJAS
\end{tabular}


Juliana Jalaludin et al. / American Journal of Applied Sciences 11 (9): 1616-1630, 2014

Table 6.Correlation between concentration of Indoor air pollutants and TNF-alpha level

\begin{tabular}{|c|c|c|c|c|}
\hline \multirow[b]{2}{*}{ TNF- $\alpha(\mathrm{pg} / \mathrm{ml})$} & \multicolumn{2}{|c|}{ Urban $(\mathrm{n}=198)$} & \multicolumn{2}{|c|}{ Rural (n = 198) } \\
\hline & $\mathrm{R}$ value & $\mathrm{P}$ value & $\mathrm{R}$ value & $\mathrm{P}$ value \\
\hline $\mathrm{PM}_{10}$ & 0.475 & $0.001 * *$ & 0.206 & $0.004 *$ \\
\hline $\mathrm{PM}_{2.5}$ & 0.493 & $0.001 * *$ & 0.356 & $0.001 * *$ \\
\hline $\mathrm{NO}_{2}$ & 0.329 & $0.001 * *$ & 0.321 & $0.001 * *$ \\
\hline
\end{tabular}

*Significant at $\mathrm{p}<0.05 ; * *$ Significant at $\mathrm{p}<0.001 ; \mathrm{N}=396$

Table 7. Factors influencing concentration TNF- $\alpha$ among school children

\begin{tabular}{llll}
\hline & Coefficient Regression $(\beta)$ & $\mathrm{t}$ & $\mathrm{p}$ \\
\hline Constant & 1.380 & 2.260 & 0.024 \\
$\mathrm{PM}_{2.5}$ & 0.084 & 2.281 & $0.001^{* *}$ \\
$\mathrm{PM}_{10}$ & 0.033 & 3.712 & $0.023 *$ \\
$\mathrm{NO}_{2}$ & -9.202 & -1.820 & 0.069 \\
\hline$*$ Significant at $p<0.05 ; * *$ Significant at $\mathrm{p}<0.001 ; \mathrm{R}^{2}=0.241$ (adjusted $\left.\mathrm{R}^{2}=0.235\right) ; \mathrm{N}=396$ &
\end{tabular}

*Significant at $\mathrm{p}<0.05 ; * *$ Significant at $\mathrm{p}<0.001 ; \mathrm{R}^{2}=0.241\left(\right.$ adjusted $\left.\mathrm{R}^{2}=0.235\right) ; \mathrm{N}=396$

\section{DISCUSSION}

\subsection{Indoor Air Levels of Particulate Matter $\left(\mathbf{P M}_{2.5}\right.$ and $\left.\mathbf{P M}_{10}\right)$}

Mean concentration level of $\mathrm{PM}_{2.5}$ in the urban school areas was nearly two times higher compared to the mean in rural schools. Unfortunately, due to insufficient information, no standard was established for $\mathrm{PM}_{2.5}$ in Malaysia. However, the level exceeded the limit when compared to the World Health Organization Air Quality Guidelines of $24 \mathrm{~h}$ period exposure $\left(12 \mu \mathrm{g} / \mathrm{m}^{3}\right)$ (USEPA, 2012). Malaysian Code of Practice (DOSH, 2010) suggests on the recommended threshold level for reparable particulates $\left(\mathrm{PM}_{10}\right)$ is set at $150 \mu \mathrm{g} / \mathrm{m}^{3}$ for $8 \mathrm{~h}$ exposure. This indoor $\mathrm{PM}_{10}$ level in urban measured during the class period is within the recommended value even though the mean concentration of urban school was recorded higher compared to rural schools. This level is also still under the threshold limit $\left(150 \mu \mathrm{g} / \mathrm{m}^{3}\right)$ by the Recommended Malaysia Ambient Air Quality Guidelines as suggested by Malaysia Department of Environment (Ismail et al., 2011). However, this permissible limit concern in $24 \mathrm{~h}$ duration exposure. An observation made in the classrooms suggests that there are a few factors that might influence the level of particulate, for instance, the distribution of particulate matters in indoor classrooms includes the presence of curtains, dust from blackboards, shelves area and ceiling fans. These factors were observed to be one of the determinants for dispersion of particulate matter in the classrooms.

Moreover, due to the geographical area as a tropical country, national primary schools in Malaysia were majorly ceiling fans ventilated and used open windows and doors as a result of having lower ventilation rates. This helps to contribute and generate indoor air pollutants and allow greater risk to the children. The particles penetrate from the outside will accumulate inside and settle down on the curtains, shelves and ceiling fans. The lack of ventilation may prevent the removal of PM especially, larger particles in the classrooms. Furthermore, primary schools today are less frequently cleaned even though they have cleaning schedule for everyday however, a mere once weekly clean being observed which might lead the particles only partly removed and hence the sediment dust remain indoors. This physical activity by the school children in the classrooms may interfere with the level of particulate remaining inside. The significant differences between indoor $\mathrm{PM}_{2.5}$ and $\mathrm{PM}_{10}$ concentrations suggest that the local surroundings might influence the concentration of the particulate in the school of urban area.

It is believed that indoor fine particulate pollutant was mainly from outdoor sources, which efficiently penetrate the indoors ambient (Diapouli et al., 2011). Thus, another contributing factor which is also known to have effects on particulate matters inside building includes the outdoor sources (Nazaroff, 2013). From the observation, $\mathrm{PM}_{2.5}$ together with $\mathrm{NO}_{2}$ trend seems to be at peak in the morning and afternoon due to traffic congestion of school buses, led to the higher amount of the fine particles and $\mathrm{NO}_{2}$ in the ambient. Particularly, the school bus has 2 cycles of fetching children in the school areas. Thus, the distance to the main road suggests a great influence to the indoor levels. The selected schools in urban area are situated near the main roads (approximately 50 to $100 \mathrm{~m}$ ), which permitted the traffic emission pollutants to be scattered inside the classrooms. One study (Norela et al., 2010) reported on 
the source of air pollution in Malaysia, emissions from mobile sources have been the major source of air pollution, contributing to at least $70-75 \%$ of the total air pollution. Furthermore, Malaysia is undergoing urbanization, thus the indoor air quality is strongly influenced by motor vehicle emission and industrial sources outdoors Average of indoor concentrations in schools around the world in countries that are undergoing vast growth in urbanization found a similar result of $\mathrm{PM}_{10}$ ranged between $43-1181.1 \mu \mathrm{g} / \mathrm{m}^{3}$. Some of these exceeded the annual WHO guideline, which is $50 \mu \mathrm{g} / \mathrm{m}^{3}$ (WHO, 2011). They also discovered that the cause is mainly because vehicles exhaust emissions from construction or urbanization activities (Chatzidiakou et al., 2012). Guo et al. (2010) also studied on the influence of outdoor air pollution on indoor level of $\mathrm{PM}_{2.5}$ in the school environment. The level of indoor particulate was mainly affected by the outdoor $\mathrm{PM}_{2.5}(\mathrm{r}=0.68$, $\mathrm{p}<0.01)$. The major outdoor pollution sources around the school were expected to be vehicle emissions. This is also agreed by (Franco et al., 2013) who conducted a more extensive study in public elementary schools in Bogota, Colombia. They found the correlation of $\mathrm{PM}_{10}$ and $\mathrm{PM}_{2.5}$ concentrations $\left(\mathrm{R}^{2}=0.86\right.$ and 0.91$)$ to be associated with an increase of traffic-related emissions.

Conversely, different result has been shown by a local study done in Kuala Terengganu, Malaysia (Ismail et al., 2010). The study conducted in three selected schools in different site of area namely commercial, sub-urban and outskirt-hilly area. The concentration level of $\mathrm{PM}_{10}$ in the classroom is $101.5 \mu \mathrm{g} / \mathrm{m}^{3}$ (commercial area) and $143.3 \mu \mathrm{g} / \mathrm{m}^{3}$ (outskirt-hilly area). On the contrary, schools located in sub-urban area are found to have a higher average concentration of $\mathrm{PM}_{10}\left(194.3 \mu \mathrm{g} / \mathrm{m}^{3}\right)$. Nevertheless, similar methods were used by the study, which utilize grab sampling techniques with the same method locate in the classroom with this current study, but with different model of equipment. The sampling was also done during the class period, only that the study (Ismail et al., 2010) had done two times measurement in 2008 .

A number of studies reported to have high levels of $\mathrm{PM}_{10}$ and $\mathrm{PM}_{2.5}$ in the classrooms (Alves et al., 2013; Heudorf et al., 2009; Goyal and Khare, 2009) with a wide range varying from 13 to $1181.1 \mu \mathrm{g} / \mathrm{m}^{3}$ and 13.5 to $359.9 \mu \mathrm{g} / \mathrm{m}^{3}$, respectively. However, this present study concentration is not as high as other developing countries due to multiple factors as the school in Malaysia has complex indoor environment, which differ in location, geographical area, weather or seasonal variation and building design. As inference, indoor and outdoor particulate matter level (Lin and
Peng, 2010) and the physical activity of school children (Morawska et al., 2009) might have a close relationship which significantly contributed to the increase of particulate matter in classrooms.

Mean concentrations of $\mathrm{NO}_{2}$ recorded in urban school were nearly 4 times higher compared to rural. According to (DOSH, 2010), the permissible exposure for $\mathrm{NO}_{2}$ was $0.2 \mathrm{ppm}$ for $8 \mathrm{~h}$ (TWA). This means exposure level of indoor $\mathrm{NO}_{2}$ in urban schools by far lower than the permissible range proposed by data statistic in Malaysia. However, if compared to $24 \mathrm{~h}$ exposure, the mean concentration of $\mathrm{NO}_{2}$ for urban school was slightly lower than the maximum permissible limit $(0.17 \mathrm{ppm})$ suggested by the Recommended Malaysia Ambient Air Quality Guidelines issued by the Department Of the Environment (DOE) since 1989 (Syed Abdul Mutalib et al., 2013). The production of $\mathrm{NO}_{2}$ in the morning showed a high concentration level, but later the concentration lessens in the afternoon due to their conversion to $\mathrm{O}_{3}$, which may lead to a low concentration level in this study. There were a few studies contributed to the understanding of $\mathrm{NO}_{2}$ in the ambient air rises from oxidization of emitted $\mathrm{NOx}$ from combustion mainly from motor engines in urban areas and it is considered to be a good marker of traffic-related air pollution Syed Abdul Mutalib et al., 2013; Lee and Dong, 2012). Thus, give a similar interpretation for this current study. Schools in urban areas had a high concentration level, which possibly due to the exposure from the outdoor pollutants as they used general (open) ventilation. Other epidemiology studies also reported on $\mathrm{NO}_{2}$ as the source derived from outdoor environment Rosenlund et al., 2009; Lamsa et al., 2013), which mostly indicates urban area. It was suggested that in urban area, motor vehicle emissions are the major source of $\mathrm{NO}_{2}$, which was also found in other studies that investigated the different levels between study areas (Tian et al., 2011; Wichmann et al., 2010).

\subsection{Prevalence of Respiratory Symptoms}

Based on the feedback made by the parents or guardians through questionnaires, indicators for respiratory symptoms showed children in urban areas were found to have great deals with respiratory symptoms. The data showed significantly differ $(\mathrm{p}<0.05)$ for cough (31.5 and 22.2\%), phlegm (20.3 and 11.1\%) and wheezing (13.4 and 2\%) in both areas, respectively. However, the total feedback made by the parents or guardians showed less responses and answers on the respiratory symptoms of chest tightness even though briefing was made to ensure they understand the 
question. This shows that the majority of the parents or guardians did not respond or may totally disagree to the questions given. The term of respiratory symptoms and confidentiality had been made clear by the researchers However, the parents or guardians especially in rural area are assumed to be close minded, which causes information bias discusses in study limitation.

Epidemiological studies have reported relationships between increased ambient of indoor air pollutants including particulate matter (Turner et al., 2011; Faustini et al., 2011; Mehta et al., 2013) and $\mathrm{NO}_{2}$ (Gillespie-Bennett et al., 2011; Meng et al., 2012) with the increase risks of respiratory tract symptoms. Other studies also correspond with the current study reported that school children in urban density communities had a significant higher prevalence of respiratory symptoms compared to those living in the rural community of low traffic exposures (Skrzypek et al., 2013; Middleton et al., 2010; Siddique et al., 2011; McCormack et al., 2009). In a cross-sectional study done in 108 schools in France among 9 to 11 years old children, the risk of asthma was significantly higher in neighborhood of schools with higher concentration of urban pollutants including $\mathrm{PM}_{10}$, $\mathrm{SO}_{2}$ and $\mathrm{NO}_{2}$ (Pénard-Morand et al., 2010). Furthermore, a few studies were done in observing the children living near main road had an increase in respiratory symptoms. A study of 1917 children in Nicosia, Cyprus found an increased risk of wheeze associated with living within $50 \mathrm{~m}$ of a main road (Middleton et al., 2010). Meanwhile, a cross-sectional study of 5733 children in Poland found that respiratory symptoms of persistent cough and seizure of dyspnea were significantly more often reported for children living more than 100 m of a main road (Skrzypek et al., 2013).

Contrarily, a study done on a prevalence of current asthma found different findings, which they indicated children at school in rural areas were most frequently reported of having wheezing for both boys and girls $(10.3 \%)$ for the aged of 6 to 15 years old (Jain et al., 2010). The differences between countries and regions are thought to be related to environmental differences, lifestyle and living conditions.

\subsection{Concentration of TNF- $\alpha$ level and Indoor Air Pollutants}

TNF- $\alpha$ act as an inflammatory mediator release when there are interaction of alveolar macrophages in the lung with atmospheric particles (Hiraiwa and Van Eeden, 2013). School children living in urban area which are exposed to high concentration of indoor air pollutants significantly have a high level of TNF- $\alpha$. This might indicate that urban school exposed to traffic emission are more polluted, leading TNF- $\alpha$ in lung to play a critical role in mediating inflammatory cell recruitment after exposure to particulate matters (Miyata and Van Eeden, 2011). Activated macrophages in human lung provide protection against infections by a variety of mechanisms including cytokine production (particularly IL-1, IL-6 and IL-8, also TNF- $\alpha$ ), which are important in mounting an immune response to infection (Barnes, 2009). Differently, rural school area which is located far from the traffic density might lead to less production of TNF- $\alpha$ level. Rise in the inflammatory cells like neutrophils and lymphocytes in sputum of school children in urban area may suggest a greater prevalence of pulmonary infection and inflammation in the city. Meanwhile, the rise in eosinophil number in sputum of urban children may indicate underlying allergy and hypersensitivity response. In essence, children chronically exposed to high level of air pollution are at a higher risk of inflammation in the lungs that may lead to lung function deficits.

A significant association between all indoor air pollutants measured and concentration of TNF- $\alpha$ were recorded at schools in urban and rural areas (Table 6). The correlation suggested that the levels of TNF- $\alpha$ was influenced by the indoor level of $\mathrm{PM}_{2.5}, \mathrm{PM}_{10}$ and the urban air particles stimulated TNF- $\alpha$ production (Montiel-Dávalos et al., 2010). Findings from this study generally corresponded with other studies, which provide evidence for particulate matters and the occurrence of TNF- $\alpha$. According to (Simões et al., 2013), TNF- $\alpha$ increases in a dose-dependent manner when alveolar macrophage in the lung of healthy human was exposed to ambient urban particles, however it produces a similar response even though that particles with different composition and size. Similar trend found in a study. Mantecca et al. (2012) in Milan, which reports a greater genotoxic potential of fine PM by inducing genotoxic effects, such as cell-cycle modification and apoptotic process activation in THP-1 cells. Exposure to $\mathrm{NO}_{2}$ have also been discussed in a few studies and known to have a correlation between the increases of $\mathrm{NO}_{2}$ exposure with the production of TNF- $\alpha$ (Lee and Dong, 2012). Taken together, correlation between the most significant concentration levels of TNF- $\alpha$ (Table 6) indicates that the $\mathrm{PM}_{2.5}$ level has the most influenced correlation ( $\mathrm{r}=$ $0.493, \mathrm{p}<0.01)$ in urban density area. $\mathrm{PM}_{2.5}$ exposure increases the inflammation response of the lung in a 
dose-dependent manner (Riva et al., 2011). In conclusion, the size-segregated particulate had significantly higher cytotoxic activity which may suggest that the incomplete combustion of traffic sources is important in air particulate pollution to the related health effects.

TNF- $\alpha$ is pro-inflammatory mediators, which may act as intermediate to alert the body of higher susceptibility (Lo Tam Loi et al., 2013; Tisoncik et al., 2012) especially in the lung (Sullivan et al., 2009). Furthermore, exposures to particulate air pollution may lead to adverse health effects which may induce airway cell damage (Revai et al., 2009). Children who are the largest population susceptible to adverse health effects are potential to develop lung disease. Thus, this biomarker of cytokines helps to indicate the potential of adverse health effect if further exposure occurred. If it does, these processes can eventually lead to a lung function reduction in children (Linares et al., 2010) and other respiratory illnesses such as asthma, COPD (Heinrich, 2011).

\subsection{Factors Influencing the Concentration of TNF- $\alpha$ Among School Children}

The current studies reported that the level of TNF$\alpha$ was highly contributed by the exposure to $\mathrm{PM}_{2.5}$ and $\mathrm{PM}_{10}$, but not by $\mathrm{NO}_{2}$. Indoor $\mathrm{PM}_{2.5}$ mostly influenced the level of TNF- $\alpha$ compared to other air pollutants $(\mathrm{t}$ $=2.281, \mathrm{p}<0.001)$. Analysis indicated that $23.5 \%$ (adjusted $\mathrm{R}^{2}=0.235$ ) from the TNF- $\alpha$ level among school children in urban group was influenced from the exposure to indoor $\mathrm{PM}_{2.5}$ level. To understand the relationship, the size of the particles might be the aspects. Particle size is an important factor that influences how particles deposit in the respiratory tract and affect human health. According to (Scherbart, 2010), larger particles have higher possibility to be deposited in the upper respiratory tract (nose and throat) and easily cleared by coughing or sneezing through mucociliary mechanism. Therefore, this larger particle size has little chance to reach the alveolar region where the lung particles removed by the resident Alveolar Macrophages (AMs) through the mechanism of producing proinflammatory cytokine. Other studies (Manigrasso and Pasquale, 2012; Berghmans et al., 2009) also suggested that it is the fine particles, which have the greatest impact on respiratory health, supported by the fact that $\mathrm{PM}_{2.5}$ penetrates the human respiratory system more efficiently into the alveolar region.
Likewise, smaller particles including $\mathrm{PM}_{2.5}$ have a higher influence in respiratory illness such as inflammation compared to larger particles (Nurul Anis Sofiah and Juliana, 2013; Mills et al., 2009). Fine particles exist in greater numbers with greater surface area than larger particles of the same mass. Due to this concern, they are generally considered to be more toxic and have a higher chance of penetrating the deepest region. Besides that, they are able to enter the systemic circulation, thus; enhances greater effect on AMs (Furuyama et al., 2009; Scherbart et al., 2011). Because of their smaller size, this fine particles tend to remain in the air for long periods of time and may be transported for hundreds (or thousands) of miles (Brook et al., 2010), thus are continuously inhaled by the school children. Furthermore, children's airways are narrower than adult's, which means they have a higher respiratory rate. They breathe in more air pollutants as they have larger lung surface areas in relation to their body weight under normal breathing circumstances, hence less inflammation or irritation is enough to obstruct the children's airways (Ismail et al., 2010; Sly and Drisse, 2013).

\subsection{Limitations}

Malaysia is still requiring much information on the knowledge of the importance of Indoor Air Qualities (IAQ) particularly in school environments. There is a large body of literature associating indoor air pollutants with changes in pulmonary health of children, but is generally focused on asthmatic children. Furthermore, limited study was found to actually relate the effects of indoor air pollutants with healthy children by using biomarkers as indicators in different areas. Besides, there may be some information bias happened when the parents or guardians may not recall well the actual incidents happened to their children. The information bias may occur in filling up the questionnaire where some of the parents or guardians may falsely give information due to diverse understanding.

\section{CONCLUSION}

This study suggested that school children in urban areas (Sri Petaling and Bandar Tun Razak) were exposed to indoor air pollutants inside classroom especially the fine particles $\left(\mathrm{PM}_{2.5}\right)$ and $\mathrm{PM}_{10}$ with significant risk of getting acute respiratory illnesses and respiratory symptoms which indicated by higher levels of Tumor Necrosis Factor-alpha (TNF- $\alpha$ ). This may trigger if the children continuously exposed for a longer period of 
time. It is now well recognized that fine particles with aerodynamic diameter of less than $2.5 \mu \mathrm{m}\left(\mathrm{PM}_{2.5}\right)$ are the primary mediators of toxicity in the lungs and the airways. While, the concentration of indoor air quality in schools particularly in an urban density area should be more concern as the levels recorded highly significant influences to the health implication of children. Our study also provides important insights that are applicable to millions of children studying in similar areas. However, this cross-sectional study was difficult to establish cause-relationship and thus other factors might influence the indoor levels. More research into pulmonary cytokine production should be carried out to understand the lung inflammation especially among children.

\section{ACKNOWLEDGEMENT}

This study was funded by University Putra Malaysia and a RUGS Project (no: 91317) and a ScienceFund Grant research project funded by Ministry of Science, Technology and Innovation, Malaysia (project code: 06-01-04-SF1582). The authors would like to thank Mrs. Safarina for technical support in the Chemical Pathological Laboratory, Department of Pathology and UPM.

\section{REFERENCES}

Alves, C., T. Nunes, J. Silva and M. Duarte, 2013. Comfort parameters and Particulate Matter (PM10 and PM2.5) in school classrooms and outdoor air. Aerosol Air Qual. Res., 13: 1521-1535. DOI:10.4209/aaqr.2012.11.0321

Ashmore, M. and C. Dimitroulopoulou, 2009. Personal exposure of children to air pollution. Atmos. Environ., 43: 128-141. DOI: 10.1016/j.atmosenv.2008.09.024

Azmi, S.Z., M.T. Latif, A.S. Ismail, L. Juneng and A.A. Jemain, 2010. Trend and status of air quality at three different monitoring stations in the Klang Valley, Malaysia. Air Qual. Atmos. Health, 3: 53-64. DOI: 10.1007/s11869-009-0051-1

Barnes, P.J., 2009. The cytokine network in chronic obstructive pulmonary disease. Am. J. Resp. Cell Mol., 41: 631-638. DOI:10.1165/rcmb.2009-0220TR

Baune, B.T., M. Camara, H. Eyre, C. Jawahar and H. Anscomb et al., 2012. Tumour necrosis factor-alpha mediated mechanisms of cognitive dysfunction. Translat. Neurosci., 3: 263-277. DOI: 10.2478/s13380-012-0027-8
Berghmans, P., N. Bleux, L. Int Panis, V.K. Mishra and R. Torfs et al., 2009. Exposure assessment of a cyclist to PM10 and ultrafine particles. Sci. Total Environ., 407: 1286-1298. DOI: 10.1016/j.scitotenv.2008.10.041

Brook, R.D., S. Rajagopalan, C.A. Pope, J.R. Brook and A. Bhatnagar et al., 2010. Particulate matter air pollution and cardiovascular disease: An update to the scientific statement from the American Heart Association. Circulation, 121: 2331-2378.

DOI: 10.1161/CIR.0b013e3181dbece1

Chatzidiakou, L., D. Mumovic and A. Summerfield, 2012. What do we know about indoor air quality in school classrooms? A critical review of the literature. Intell. Build. Internat, 4: 228-259. DOI: 10.1080/17508975.2012.725530

Delacourt, C., S. Herigault, C. Delclaux and A. Poncin, M. Levame et al., 2002. Protection against acute lung injury by intravenous or intratracheal pretreatment with EPI-HNE-4, a new potent neutrophil elastase inhibitor. Am. J. Resp. Cell Mol., 26: 290-297. DOI: 10.1165/ajrcmb.26.3.4611

Diapouli, E., K. Eleftheriadis, A.A. Karanasiou, S. Vratolis and O. Hermansen et al, 2011. Indoor and outdoor particle number and mass concentrations in athens. Sources, sinks and variability of aerosol parameters. Aerosol Air Qual. Res., 11: 632-642. DOI: 10.4209/aaqr.2010.09.0080

DOSH, 2010. Code of Practice on Indoor Air Quality. Ministry of Human Resources Malaysia. Department of Safety and Health.

DSM, 2011. Population distribution and basic demographic characteristic report 2010. statistics.gov.my.

Edwards, J. and C. Langpap, 2012. Fuel choice indoor air pollution and children's health. Environ. Dev. Econ., 17: 379-406. DOI: 10.1017/S1355770X12000010

Elahi, M.M., K. Asotra, B.M. Matata and S.S. Mastana, 2009. Tumor necrosis factor alpha-308 gene locus promoter polymorphism: An analysis of association with health and disease. Biochim. Biophys. Acta, 1792: 163-172. DOI: 10.1016/j.bbadis.2009.01.007 
Faustini, A., M. Stafoggia, G. Berti, L. Bisanti and M. Chiusolo, 2011. The relationship between ambient particulate matter and respiratory mortality: A multi-city study in Italy. Eur. Respir. J., 38: 538547. DOI: 10.1183/09031936.00093710

Franco, J.F., N.Y. Rojas, O.L. Sarmiento and E. Behrentz, 2013. Urban air pollution in schoolrelated microenvironments in Bogota, Colombia. Ingeniería Investigación, 33: 42-48.

Furuyama, A., S. Kanno, T. Kobayashi and S. Hirano, 2009. Extrapulmonary translocation of intratracheally instilled fine and ultrafine particles via direct and alveolar macrophage-associated routes. Arch. Toxicol., 83: 429-437. DOI: 10.1007/s00204-008-0371-1

Gibson, P.G., 1998. Use of induced sputum to examine airway inflammation in childhood Asthma. J. Allergy Clin. Immunol., 102: S100-S101. DOI: 10.1016/S0091-6749(98)70039-9

Gillespie-Bennett, J., N. Pierse, K. Wickens, J. Crane and P. Howden-Chapman et al., 2011. The respiratory health effects of nitrogen dioxide in children with asthma. Eur. Respir. J., 38: 303-309. DOI: 10.1183/09031936.00115409

Gilliland, F., 2009. Outdoor air pollution genetic susceptibility and asthma management: Opportunities for intervention to reduce the burden of asthma. Pediatrics, 123: S168-S173. DOI: 10.1542/peds.2008-2233G

Goyal, R. and M. Khare, 2009. Indoor-outdoor concentrations of RSPM in classroom of a naturally ventilated school building near an urban traffic roadway. Atmos. Environ., 43 6026-6038. DOI: 10.1016/j.atmosenv.2009.08.031

Gül, H., E. Gaga, T. Döğeroğlu, O. Özden and O. Ayvaz et al., 2011. Respiratory health symptoms among students exposed to different levels of air pollution in a Turkish city. Int. J. Environ. Res. Public Health, 8: 1110-1125. DOI: 10.3390/ijerph8041110

Guo, H., L. Morawska, C. He, Y.L. Zhang and G.A. Ayoko et al., 2010. Characterization of particle number concentrations and $\mathrm{PM}_{2.5}$ in a school: Influence of outdoor air pollution on indoor air. Environ. Sci. Pollut. R., 17: 1268-1278. DOI: 10.1007/s11356-010-0306-2

Heinrich, J., 2011. Influence of indoor factors in dwellings on the development of childhood asthma. Int. J. Hyg. Envir. Heal., 214: 1-25. DOI: 10.1016/j.ijheh.2010.08.009
Heudorf, U., V. Neitzert and J. Spark, 2009. Particulate matter and carbon dioxide in classrooms. The impact of cleaning and ventilation. Int. J. Hyg. Envir. Heal., 212: 45-55. DOI: 10.1016/j.ijheh.2007.09.011

Hiraiwa, K. and S.F. Van Eeden, 2013. Contribution of lung macrophages to the inflammatory responses induced by exposure to air pollutants. Mediat. Inflamm., 2013: 1-10. DOI: 10.1155/2013/619523

Ismail, I., R. Laiman and H. Ahmad, 2011. Study of particulate matter (PM10) concentration and elemental composition at damansara-puchong highway. Proceedings of the International Conference on Biology, Environment and Chemistry, (EC' 11), IACSIT Press, Singapoore pp: 339-343.

Ismail, M., N.Z. Mohd Sofian and A.M. Abdullah, 2010. Indoor air quality in selected samples of primary schools in Kuala Terengganu, Malaysia. Environ. Asia, 3: 103-108.

Jain, A., H.V. Bhat and D. Acharya, 2010. Prevalence of bronchial asthma in rural Indian children: A cross sectional study from South India. Indian J. Pediatr., 77: 31-35. DOI: 10.1007/s12098-009-0308-6

Lamsa, L.N., R.V. Martin, D.D. Parrish and N.A. Krotkov, 2013. Scaling relationship for $\mathrm{NO}_{2}$ pollution and urban population size: A satellite perspective. Environ. Sci. Technol., 4: 7855-7861. DOI: $10.1021 / \mathrm{es} 400744 \mathrm{~g}$

Lee, S.C. and M. Chang, 2000. Indoor and outdoor air quality investigation at schools in Hong Kong. Chemosphere, 41: 109-113. DOI: 10.1016/S00456535(99)00396-3

Lee, Y.L. and G.H. Dong, 2012. Air pollution and health effects in children. Air Pollut. Monitor., Modell. Health. DOI: $10.5772 / 32965$

Lin, C.C. and C.K. Peng, 2010. Characterization of Indoor $\mathrm{PM}_{10}, \mathrm{PM}_{2.5}$ and ultrafine particles in elementary school classrooms: A review. Environ. Eng. Sci., 27: 915-922. DOI: 10.1089/ees.2010.0175

Linares, B., J.M. Guizar, N. Amador, A. Garcia and V. Miranda et al., 2010. Impact of air pollution on pulmonary function and respiratory symptoms in children. Longitudinal repeated-measures study. BMC Pulmonary Med., 10: 1-9. DOI: 10.1186/1471-2466-10-62

Ling, O.H.L., K.H. Ting, A. Shaharuddin, A. Kadaruddin and M.J. Yaakob, 2010. Urban growth and air quality in Kuala Lumpur city, Malaysia. Environ. Asia. 3:123-128. 
Liu, M., D. Wang, Y. Zhao, Y. Liu and M. Huang et al., 2013. Effects of outdoor and indoor air pollution on respiratory health of Chinese children from 50 kindergartens. J. Epidemiol., 23: 280-287. DOI: 10.2188/jea.JE20120175

Lo Tam Loi, A.T., S.J. Hoonhorst, L. Franciosi, R. Bischoff and R.F. Hoffmann et al., 2013. Acute and chronic inflammatory responses induced by smoking in individuals susceptible and nonsusceptible to development of COPD: From specific disease phenotyping towards novel therapy, protocol cross-sectional study. BMJ Open, 3: 1-10. DOI: 10.1136/bmjopen-2012002178

Manigrasso, M. and A. Pasquale, 2012. Fast evolution of urban ultrafine particles: Implications for deposition doses in the human respiratory system. Atmos. Environ., 51: 116-123. DOI: 10.1016/j.atmosenv.2012.01.039

Mantecca, P., M. Gualtieri, E. Longhin, G. Bestetti and P. Palestini et al., 2012. Adverse biological effects of Milan urban PM looking for suitable molecular markers of exposure. Chem. Ind. Chem. Eng. Q., 18: 635-641. DOI: 10.2298/CICEQ120206114M

Masron, T., U. Yaakub, N. Mohd A.A.S. Mokhtar, 2012. Population and spatial distribution of urbanisation in Peninsular Malaysia 19572000. Malaysia J. Society Space, 8: 20-29.

McCormack, M.C., P.N. Breysse, C. Elizabeth, N.N. Matsui and D.A. Hansel et al., 2009. In-home particle concentrations and childhood asthma morbidity for the center for childhood asthma in the urban environment. Environ. Health Persp., 117: 294-298. DOI: 10.1289/ehp. 11770

Mehta, S., H. Shin, R. Burnett, T. North and A.J. Cohen, 2013. Ambient particulate air pollution and acute lower respiratory infections: A systematic review and implications for estimating the global burden of disease. Air Qual. Atmos. Health, 6: 69-83. DOI: 10.1007/s11869011-0146-3

Meng, Q.Y., D. Svendsgaard, D.J. Kotchmar and J.P. Pinto, 2012. Associations between personal exposures and ambient concentrations of nitrogen dioxide: A quantitative research synthesis. Atmos. Environ., 57: 322-329. DOI: 10.1016/j.atmosenv.2012.04.035

Mercola, J., 2011. Inside your home: The ugly invaders which can make you sick. mercola.com.
Middleton, N., P. Yiallouros, N. Nicolaou, S. Kleanthous and S. Pipis et al., 2010. Residential exposure to motor vehicle emissions and the risk of wheezing among 7-8 year-old schoolchildren: A citywide cross-sectional study in Nicosia, Cyprus. Environ. Health, 9: 1-17. DOI: 10.1186/1476-069X-9-28

Mills, N.L., K. Donaldson, P.W. Hadoke, N.A. Boon and W. MacNee et al., 2009. Adverse cardiovascular effects of air pollution. Nat. Clin. Pract. Cardiovasc. Med., 6: 36-44. DOI: 10.1038/ncpcardio1399

Miyata, R. and S.F. van Eeden, 2011. The innate and adaptive immune response induced by alveolar macrophages exposed to ambient particulate matter. Toxicol. Appl. Pharm., 257: 209-226. DOI: 10.1016/j.taap.2011.09.007

Mohd Sofian, N.Z. and M. Ismail, 2012. Indoor and outdoor relationships of respirable suspended particulate matter at primary schools in Kuala Terengganu, Malaysia. Indoor Built Environ., 21: 423-431. DOI: 10.1177/1420326X11420180

Montgomery, S.L. and W.J. Bowers, 2012. Tumor necrosis factor-alpha and the roles it plays in homeostatic and degenerative processes within the central nervous system. J. Neuroimmune Pharm., 7: 42-59. DOI: $10.1007 / \mathrm{s} 11481-011-9287-2$

Montiel-Dávalos, A., M. Ibarra-Sánchez, J.L. VenturaGallegos, E. Alfaro-Moreno and R. López-Marure, 2010. Oxidative stress and apoptosis are induced in human endothelial cells exposed to urban particulate matter. Toxicol. Vitro, 24: 135-141. DOI: 10.1016/j.tiv.2009.08.004

Morawska, L., G.R. Johnson, Z.D. Ristovski, M. Hargreaves and K. Mengersen et al., 2009. Size distribution and sites of origin of droplets expelled from the human respiratory tract during expiratory activities. J. Aerosol Sci., 40: 256-269. DOI: 10.1016/j.jaerosci.2008.11.002

Musa, M., A.A. Jemain and W.Z. Wan Zin, 2013. Scaling and persistence of ozone concentrations in Klang Valley, Malaysia. J. Qual. Measurement Analysis., 9: 9-20.

Nazaroff, W.W., 2013. Exploring the consequences of climate change for indoor air quality. Environ. Res. Lett. DOI: 10.1088/1748-9326/8/1/015022

Naziah, M.S., N.K. Syahrul, S. Raha and S.M. Naziatul et al., 2011. Indoor air quality at school: Ventilation Rates and Its impacts towards children-a review. Proceedings of the 2nd International Conference on Environmental Science and Technology, (ST’ 11), IACSIT Press, Singapore. 
Ngah, I., 2010. Rural development in malaysia.

Norela, S., A. Maimon, B.S. Ismail and S. AlBateyneh, 2010. Concentration of air pollutants during working and non-working days in the Kuala Lumpur City Centre, Malaysia. World Applied Sci. J., 8: 1013-1021.

Nurul Anis Sofiah, F. and J. Juliana, 2013. Indoor Particulate Matter $2.5\left(\mathrm{PM}_{2.5}\right)$ and lung function among children living near busy road in Cheras, Kuala Lumpur. Health Environ. J., 4: 1-19.

Padhi, B. K., P. K. Padhy, L. Sahu, V. K. Jain and R. Ghosh, 2010. Assessment of intra-urban variability in indoor air quality and its impact on children's health. Air Qual. Atmos. Health, 3: 149-158. DOI: 10.1007/s11869-010-0063-X

Pegas, P.N., C.A. Alves, M.G. Evtyugina, T. Nunes and M. Cerqueira et al., 2010. Indoor air quality in elementary schools of Lisbon in spring. Environ. Geochem. Health., 33: 455-468. DOI: 10.1007/s10653-010-9345-3

Pénard-Morand, C., C. Raherison, D. Charpin, C. Kopferschmitt and F. Lavaud et al., 2010. Long-term exposure to close-proximity air pollution and asthma and allergies in urban children. Eur. Respir. J., 36: 3340. DOI: $10.1183 / 09031936.00116109$

Reuters, 2013. More air pollution deaths per year than from AIDS malaria: UN. The Huffington Post.

Revai, K., J.A. Patel, J.J. Grady, R. Matalon and T. Chonmaitree et al., 2009. Association between cytokine gene polymorphisms and risk for upper respiratory tract infection and acute Otitis media. Krystal, Clin. Infect. Dis., 49: 257-261. DOI: 10.1086/599833

Riva, D.R., C.B. Magalhães, A.A. Lopes, T. Lanças and T. Mauad et al., 2011. Low dose of fine particulate matter $\left(\mathrm{PM}_{2.5}\right)$ can induce acute oxidative stress, inflammation and pulmonary impairment in healthy mice. Inhal. Toxicol., 23: 257-267. DOI: 10.3109/08958378.2011.566290

Rosenlund, M., F. Forastiere, D. Porta, M. De Sario and C. Badaloni et al., 2009. Traffic-related air pollution in relation to respiratory symptoms, allergic sensitisation and lung function in schoolchildren. Thorax, 64: 573580. DOI: 10.1136/thx.2007.094953

Scherbart, A.M., 2010. Mechanisms and consequences of particle uptake in alveolar macrophages. inaugural-dissertation. Düsseldorf, Oktober.

Scherbart, A.M., J. Langer, A. Bushmelev, D. van Berlo and P. Haberzettl et al., 2011. Contrasting macrophage activation by fine and ultrafine titanium dioxide particles is associated with different uptake mechanisms. Particle and Fibre Toxicol., 8: 1-19. DOI: 10.1186/1743-8977-8-31
Shaharom, N., 2013. Indoor air quality and prevalence of sick building syndrome among office workers in two different offices in Selangor. Am. J. Applied Sci., 10: 1140-1147. DOI: 10.3844/ajassp.2013.1140.1147

Siddique, S., M.R. Ray and T. Lahiri, 2011. Effects of air pollution on the respiratory health of children: a study in the capital city of India. Air Qual. Atmos. Health, 4: 95-102. DOI: 10.1007/s11869-010-0079-2

Simões, R.L., M.A. Arruda, C. Canetti, C.H. Serezani and I.M. Fierro, 2013. Proinflammatory responses of heme in alveolar macrophages: Repercussion in lung hemorrhagic episodes. Mediat. Inflamm., 1-11. DOI: 10.1155/2013/946878

Skrzypek, M., J.E. Zejda, M. Kowalska and E.M. Czech, 2013. Effect of residential proximity to traffic on respiratory disorders in school children in Upper Silesian Industrial Zone, Poland. Int. J. Occup. Med. Env., 26: 83-91. DOI: 10.2478/S13382-013-0078-2

Sly, L. and M.N.B. Drisse, 2013. Children's vulnerability to their environment. J. Environ. Immunol. Toxicol., 1:58-65. DOI: 10.7178/jeit.6

Sullivan, D.E., M. Ferris, H. Nguyen, E. Abboud and A.R. Brody, 2009. TNF-induces TGF-1 expression in lung fibroblasts at the transcriptional level via AP-1 activation. J. Cell. Mol. Med., 13: 1866-1876. DOI: 10.1111/j.15824934.2009.00647.x

Syed Abdul Mutalib, S.N., H. Juahir, A. Azid, S. Mohd Sharif and M.T. Latif et al., 2013. Spatial and temporal air quality pattern recognition using environmetric techniques: A case study in Malaysia. Environ. Sci. Processes Impacts, 15: 1717-1728. DOI: 10.1039/c3em00161j

Tabaku, A., G. Bejtja, S. Bala, E. Toci and J. Resuli, 2011. Effects of air pollution on children's pulmonary health. Atmos. Environ., 45: 7540-7545. DOI: 10.1016/j.atmosenv.2010.07.033

Tian, L., S.R. Hossain, H. Lin, K.F. Ho and S.C. Lee et al., 2011. Increasing trend of primary $\mathrm{NO}_{2}$ exhaust emission fraction in Hong Kong. Environ. Geochem. Hlth., 33: 623-630. DOI: 10.1007/s10653-011-9375-5

Tisoncik, J.R., M.J. Korth, C.P. Simmons, J. Farrar and T.R. Martin et al., 2012. Into the eye of the cytokine storm. Microbiol. Mol. Biol. R., 76: 16-32. DOI: 10.1128/MMBR.05015-11 
Turner, M.C., D. Krewski, C.A. Pope, Y. Chen and S.M. Gapstur et al., 2011. Long-term ambient fine particulate matter air pollution and lung cancer in a large cohort of never-smokers. Am. J. Resp. Crit. Care, 184: 1374-1381. DOI: 10.1164/rccm.201106-10110C

USEPA, 2011. Indoor Air: What are the trends in indoor air quality and their effects on human health? United States Environmental Protection Agency.

USEPA, 2012. EPA revises the national ambient air quality standards for particle pollution. United States Environmental Protection Agency.
WHO, 2011. Air quality and health. World Health Organization.

Wichmann, J., T. Lind, M.A.M. Nilsson and T. Bellander et al., 2010. $\mathrm{PM}_{2.5}$, soot and $\mathrm{NO}_{2}$ indooroutdoor relationships at homes, pre-schools and schools in Stockholm, Sweden. Atmos. Environ., 44: 4536-4544. DOI: 10.1016/j.atmosenv.2010.08.023

Zakaria, J., L. Sann and Z. Hashim, 2012. Asthma severity and environmental health risk factor among asthmatic primary school children in the selected areas. Am. J. Applied Sci., 9: 1553-1560. DOI: 10.3844/ajassp.2012.1553.1560 